\title{
Evaluation of the nutritional and microbiological status of co-fermented cereals/cowpea 'OGI'.
}

\author{
*Oyarekua, M. A. \\ Department of Biological and Chemical Sciences, University of Science and Technology, \\ P.M.B 306, Ifaki-Ekiti.(USTI) Nigeria.
}

\begin{abstract}
This study investigated nutritional, viscosity and microbial status of co-fermented cereal /cowpea. Standard Methods According to AOAC (2005) were used for proximate compositions. Mineral Safety Index (MSI) was calculated. Characterization of isolates were by macroscopic, microscopic and biochemical tests. Viscosity was measured using Rotational Viscometer. Protein contents were comparable. Crude fibre was higher in millet/cowpea and lipid in sorghum/cowpea. Both samples had comparable $\mathrm{K}, \mathrm{Cu}, \mathrm{Zn}$ and $\mathrm{Mn}$ values. $\mathrm{Fe}$ and $\mathrm{Na}$ values were higher in millet/cowpea and $\mathrm{P}, \mathrm{Ca}$ and $\mathrm{Mg}$ in sorghum/cowpea. Mineral Safety Index for copper, phosphorus and zinc were lower in both samples than tabulated required daily allowance (RDA) for infants; while sodium was comparable to RDA values. Iron in millet/cowpea was higher than RDA and magnesium in sorghum/cowpea. Millet/cowpea had more yeasts, moulds and enterobacteriaceae. Total plate count was more in sorghum/cowpea and lactic acid bacteria count more in millet/cowpea. Probable organism isolated from sorghum/cowpea was Lactobacillus plantarun and Lactobacillus brevis from millet/cowpea. Consistency values were comparable at $12 \%$ flour concentration for both samples; viscosity was more reduced at $12 \%$ in millet/cowpea. Sorghum/cowpea ogi had acceptable values of $\mathrm{Ca}, \mathrm{Mg}$, crude fiber and lipid contents. Millet/cowpea ogi might be more desirable in terms of viscosity.
\end{abstract}

Keywords: co-fermentation, minerals, viscosity, microbial-status

\section{INTRODUCTION}

Complementary foods are the first nutrients providing foods given to infants in addition to breast milk after six months of age and are consumed by over $90 \%$ of infants over 6 months of age in Nigeria. Prevalence of under nutrition and micronutrients deficiency is high among infants and young children of 6-23 months old. During complementary feeding, infant is very vulnerable nutritionally therefore; introduction of semi-solid foods at the expense of breast milk must provide adequate nutrients for the rapid phase of growth and development. They are specially prepared to meet the particular nutrient and physiological needs of the infant (FAO/WHO, 1998). A complementary food must have a high calorie and micronutrient density, be in a "low bulk" or drinkable form, free of bacterial contamination, and must be of a quantity that can be consumed at one feeding. In Nigeria, the first complementary food is usually a thin cereal porridge made from fermented maize, millet, or sorghum. This porridge is called ogi it and provides $20-26 \mathrm{kcal} / \mathrm{kg}$ per day and Nigerian infants have an average energy density of $0.26 \mathrm{kcal} / \mathrm{g}$ (Brown,et al., 1998).
Cereals are the most important staple food being the major sources of carbohydrates. Compositionally cereals consist of $12-14 \%$ water, $65-75 \%$ carbohydrates; $2-6 \%$, lipids and 7-12\% protein on dry weight basis. In their natural form whole grain cereals are also significant contributor of vitamins, minerals like manganese, zinc, copper and magnesium and considerable iron but its bioavailability is low. This results in incidence of iron deficiency anemia, however processes like fermentation has improved the chemical bioavailability of iron. (Dada and Muller 1970).

Millet (Pennistum vulgare) starch granules are half the size of sorghum starch granules. The starch consists of $68 \%$ amylopectin and $32 \%$ pectin and it is not easily hydrolyzed by alpha-amylase. Pearl millet gelatinizes at the temperature at which sorghum and maize starch gelatinizes. Millet unlike sorghum is not toxic at any stage. Millet contains higher protein content (8-19\%) than any other cereal grown under similar conditions. The mineral value of millet is similar to that of sorghum. Pearl millet has, lower percent crude protein, higher protein and higher oil (fat) content compared to sorghum. 
Sorghum, (Sorghum bicolor L. moench) is one of the most important food constituents in semi-arid parts of Africa and Asia. The color of the endosperm, range from white, to yellow, brown or black. The pericarp and the testa constitute about $6 \%$ of the dry weight of the sorghum grain. It contains a range of $9-20 \%$ poor quality protein. The embryo and scutellum of embryo contains most minerals, lipids. The sorghum kernel is composed of starch, cellulose and simple sugars.

Cowpea (Vigna unguiculata (L) Walp.) is one of the most important food legumes grown throughout the tropics and the black-eyed variety is mostly grown in West Africa. Dry cowpea has little vitamin and more than human requirements of thiamin and nicotinic acid. Methionine is the most limiting amino acid. Cowpea provides a significant level of dietary protein and lysine in regions of chronic protein shortage like Nigeria. Studies have shown several applications of legume proteins which have a potential role as substrates for the development of complementary foods due to the high nutritional value (Pereira et al., 2009). Various processing methods have been employed to improve the nutritional quality and utilization of cowpeas. Many efforts had been made to improve the nutritive value of cereal by supplementation with legumes. Akinrele and Edwards (1971) fortified sour maize pap with soya and reported that an adequate nutritive quality food suitable for kwashiokored children. Fermentation has been reported to improve the nutritive value of cowpea (Fields, 1980). Osundahunsi, and Aworh (2002) observed improved 70:30 mixture of maizel soybean; Ojofeitimi et al., (1984) studied black-eyed cowpea (ewa) and maize gruel ogi as and reported that babies on ewa-ogi showed disappearance of physical kwashiorkor. (Bressani, 1985). Wannik, et al., 1994) investigated the effect of roasting and fermentation (with natural inocula) on the viscosity of maize-sorghum-soya porridges and reported that natural fermentation of mixed ingredients resulted in lower porridge viscosities when $\mathrm{pH}$ was 5.0-5.5, at lower $\mathrm{pH}$ viscosity of final porridge increased while roasting of the mixture resulted in higher viscosity.

Microbial fermentation provides a way to food preservation, reduction in volume of material to be transported, inhibition of microbial growth, improvement of appearance and taste of some foods and reduce the energy required for preparing food, safer food products and enhancement of nutritive value. (Afoakwa, et al., 2007). Not many studies have been carried out on co-fermentation of cereals and legumes by using traditional processing methods of fermentation. Therefore, this study was undertaken to formulate inexpensive processing cofermentation technique that can be carried out at household level to produce suitable complementary food mixtures with low- cost locally available raw materials that are bio-compatible.

\section{MATERIALS AND METHODS}

Materials preparation: The millet, sorghum, and cowpea grains were purchased at Bodija market, a popular market at Ibadan, Southwestern part of Nigeria. Winnowing and hand sorting obtained the grains. The $1000 \mathrm{~g}$ maize was mixed with $300 \mathrm{~g}$ cowpea, soaked at ambient temperature for 72 hours; the mixture was wet-milled and sieved. The mixture was allowed to settle in the steeping water for 24 hours after which the sediment was dewatered, sun dried, milled and packed in polythene bag ( $3 \mathrm{~mm}$ in thickness) and stored in the freezer until needed.

Microbiological Evaluations: The microbial status of millet/cowpea and sorghum/cowpea ogi (70:30w/w), were investigated.

Isolation procedure: Steep liquor (10ml portions) was aseptically removed every 24 hours over a 72 hour period and serially diluted; using different sterile $1.0 \mathrm{ml}$ pipette $0.1 \mathrm{ml}$ of $10^{-1}$ to $10^{-8}$ dilutions. Ten serial dilutions of were done for each sample. The various samples were plated out by mixing with MRS agar medium in McCartney bottles and poured aseptically into sterile Petri dishes for lactic acid bacteria isolation. After solidifying, the Petri dishes were incubated in anaerobic jars using BTL Gas Park (hydrogen and carbon dioxide generators). The colonial morphology and cellular characteristic for the various colonies obtained were studied. The total viable counts were made on plate count agar (PCA). Yeasts and mould counts were determined on malt extract agar (MEA) containing $100 \mathrm{ml}$ - streptomycin and MacConkey agar for Enterobacteriacae. Plates were incubated at $30^{\circ} \mathrm{C}$ for $24 \mathrm{~h}$. For the PCA $30^{\circ} \mathrm{C}$, for $48 \mathrm{~h}$ for MRS, $37^{\circ} \mathrm{C}$ for $24 \mathrm{~h}$ for MacConkey and 4-5 days for the MEA medium. After the incubation period the plates were observed for bacterial growth and the colonies were randomly selected. Cultures were sub-cultured and repeated streaking was done on sterile MRS plates to obtain pure culture.

Characterization of Isolates: This was done by employing macroscopic, microscopic, and 
biochemical tests. Identification: Pure growth was heavily inoculated in the modified MRS broth containing the following sugar: glucose (plus Durham's tube) lactose, sucrose, salicin, mannitol, sorbose and xylose in MRS broth containing 2\% glucose and in which the ammonium citrate has been replaced by $0.3 \%$ arginine for arginine hydrolysis, and in MRS broth containing $4 \%$ sodium chloride. These were incubated at $28^{\circ} \mathrm{C}-30^{\circ} \mathrm{C}$ for $3-$ 4 days. Also, inoculated tubes of MRS broth were incubated at $15^{\circ} \mathrm{C}$ and $45^{\circ} \mathrm{C}$.

Proximate Composition: The levels of moisture content was determined by desiccation in oven at $105^{\circ} \mathrm{C}$ until constant weight according to AOAC (2005). The levels of crude fibre, crude protein and lipid content were determined according to AOAC(2005). Carbohydrates was obtained by difference sample was analyzed in triplicates. Dry matter was estimated by difference of moisture content.

Minerals Determination: The mineral contents were determined according AOAC2005 using atomic absorption spectrophotometer. (GBC Scientific Equipment Pty Ltd.) Phosphorus was determined using spectrophotometer at 430nm.

Viscosity procedure: Simple empirical measurement for consistency of each gruel was determined using Botswick Consistometer.(Laomat CEDEX). Four to $18 \%$ (on dry matter basis weight 'ogi' gruel cake: water) were mixed and stirred constantly on hot plate at $80^{\circ} \mathrm{C}$. At the first appearance of first appearance of first bubble, cooking was timed to 5 minutes after which was cooled to $45^{\circ} \mathrm{C}$. The first compartment was filled with $100 \mathrm{ml}$ of each co-fermented cereal/cowpea gruel. At time $=0$, the trigger was pressed to release the gate of the first compartment to allow gruel flow by gravity to the second compartment. The distance the gruel covered in 30seconds was measured in millimeters as the Bostwick Consistency reading (i.e flow in $\mathrm{mm} / 30$ seconds). Dry matter of gruel was determined according to AOAC ( 2005).

Viscosity measurement was determined using Haake VT500 viscometer with coaxial gruel spindle .The computerized viscometer was operated to record the viscosity of gruel for 10 minutes shear rate SV-Din spindle at $83.21 \mathrm{sec}-1$ (64.5rpm), gruel temperature $=45^{\circ} \mathrm{C}$. Readings were taken in Pascal seconds (P. a. S.) after 10 minutes of spindle rotation when they became stable .The dry matter values were compared with consistency and viscosity measurements.

\section{RESULTS}

There was significant reduction in the $\mathrm{pH}$ of cofermenting mixtures by 72 hours leading to acid production (Table 1). The acidic nature of the product could be due to the production of lactic acid by microorganisms associated with cereal dough fermentation. The total acidity may be connected with the depletion of sugars to yield lactic acids which would prove beneficial in the control of spoilage and pathogenic organisms.

Table1. The pH and Titrable Acidity of co-fermented millet/cowpea and sorghum/cowpea over 72 hour fermentation period

\begin{tabular}{|l|l|l|}
\hline Sample & TA (72hr) & $\mathrm{pH}(72 \mathrm{hr})$ \\
\hline LM/C & 0.37 & 4.12 \\
UM/C & 0.12 & 6.29 \\
LS/C & 0.39 & 3.83 \\
US/C & 0.09 & 6.40 \\
\hline
\end{tabular}

Key: $\mathrm{MC}=$ Laboratory fermented millet/cowpea UMC= Unfermented millet/cowpea, SC= Laboratory fermented sorghum/cowpea, USC= Unfermented sorghum/cowpea. Each value is mean of triplicate values.

Table 2 show the biochemical characteristics of microorganisms isolated from the co-fermented samples. Gram-positive rods isolated from millet/cowpea and sorghum/cowpea all had positive growth at $15^{\circ} \mathrm{C}$. While at $45^{\circ} \mathrm{C}$, millet/cowpea 'ogi' had no growth but there were growth in sorghum/cowpea 'ogi'. Sorghum /cowpea isolates fermented (with gas production), lactose, sucrose, salicin, and mannitol did not produce ammonia from arginine but produced growth in $4 \% \mathrm{NaCl}$. Probable identity was Lactobacillus plantarum. Millet/cowpea isolates fermented (with gas production) sucrose, salicin and mannitol but did not ferment lactose and sorbose. The isolates produced ammonia from arginine and had growth in $4 \% \mathrm{NaCl}$. Probably identity was Lactobacillus brevis. The presence of $L$. brevis might give stronger aroma in agreement with Teniola \& Odunfa (2002). Colonies of sorghum/cowpea were whitish and small about 1$2 \mathrm{~mm}$ in width while colonies from millet/cowpea were glossy, creamy, and raised; with entire edges and width of about $2-3 \mathrm{~mm}$. 
Table2: Biochemical characteristics of isolated microorganisms from fermented sorghum/ cowpea ogi and millet/cowpea ogi

\begin{tabular}{|c|c|c|}
\hline Parameter & Sorghum/cowpea ogi & Millet/cowpea ogi \\
\hline Cultural Characteristics & Whitish small colonies about $1-2 \mathrm{~mm}$ & Glossy, creamy raised colonies, \\
\hline Gram reaction & GPR & about $2-3 \mathrm{~mm}$ \\
\hline Catalase reaction & & GPR \\
\hline Growth at $15^{\circ} \mathrm{C}$ & + & \\
\hline Growth at $45^{\circ} \mathrm{C}$ & + & - \\
\hline Fermentation of: & + & - \\
\hline Lactose & + & + \\
\hline Sucrose & + & + \\
\hline Salicin & + & + \\
\hline Mannitol & - & + \\
\hline Sorbose & - & - \\
\hline Xylose & - & + \\
\hline Ammonia from arginine & + & + \\
\hline $\begin{array}{l}\text { Growth in } 4 \% \text { sodium chloride } \\
\text { Probable Identity }\end{array}$ & L. plantarum & $\stackrel{+}{\text { L. brevis }}$ \\
\hline
\end{tabular}

Lactobacillus species including $L$. plantarum, $L$. brevis were the major isolates; in terms of colony forming units (Table 3 ). The small number of units of Enterobacteriaceae and other Gram-negative bacteria showed that their growth might have been inhibited due to the presence of lactic acid, resulting in the decrease in the decrease of $\mathrm{pH}$ to 4.0 this agrees with Oyeyiola (1990, Chavan 1998) that $L$. plantarum, was one of the major the major isolates during the production of fermented cereal 'ogi'. The predominance of $L$. plantarum, $L$. brevis in this study may be due to secretion of other compounds probably from cowpea which might inhibit the growth of other bacteria and yeasts in the fermenting medium. The subsequent disappearance of molds/yeasts was probably due to the low oxygen tension in the fermenting medium. Workers have found species of Saccharomyces and Candida in spontaneous lactic acid fermentation in cereals (Mbata,et al., 2007). The decrease of total plate counts in cereals 'ogi' than cereals/cowpea 'ogi' might be due to mixed micro flora of each cereal and cowpea that might also indicate a range of enzymes like glycoamylase which degrades starch and yeasts which ferments parts of glucose thereby making lactic acid bacteria to co- exist with yeast in proto-cooperative manner this agrees with the report of Nout (2009). The isolation of Saccharomyces spp, Lactobacillus spp and endospore forming bacteria reported in this work agreed with an earlier report that microorganisms like L. plantarum, Streptococcus lactis, Saccharomyces cerevisae, are associated with cereals fermentation while they reported that the bacteria with strongest proteolytic activity were gram positive endospore rod-shaped bacteria present throughout 72 hour fermentation of the legume thua nao were Bacillus spp. (Danjanta, et al., 2009).

Both homo and hetero fermentative bacteria were found at the end of our fermentation this finding agreed with that of Mbata,et al., (2009), who reported both homo and hetero fermentative lactic acid at the end of fermentation of maize flour fortified with bambara nuts (Vigna subterranean L.) but contrary to the finding of Lonner,et al., (1986) who reported that only homo fermentative bacteria were the isolates from final sour dough of fermented cereal. The variation in our work might be due to the presence of cowpea and type of cereals.

Table 3. Microbial load (log $\left.\mathrm{cfu}^{-1}\right)$ of co-fermented and fermented samples after 72 hours fermentation time.

\begin{tabular}{|l|l|l|l|l|}
\hline Sample & $\begin{array}{l}\text { Total } \\
\text { plate } \\
\text { count }\end{array}$ & $\begin{array}{l}\text { Lactic } \\
\text { Acid } \\
\text { Bacteria }\end{array}$ & $\begin{array}{l}\text { Yeasts/ } \\
\text { moulds }\end{array}$ & $\begin{array}{l}\text { Enterobactere } \\
\text { aceae }\end{array}$ \\
\hline LM/C & $2.8 \times 10^{9}$ & $1.6 \times 10^{6}$ & $1.0 \times 10^{2}$ & $1.5 \times 10^{1}$ \\
LM & $3.5 \times 10^{8}$ & $2.7 \times 10^{6}$ & $3.2 \times 10^{1}$ & $2.0 \times 10^{1}$ \\
LS/C & $4.2 \times 10^{8}$ & $1.3 \times 10^{6}$ & $2.0 \times 10^{1}$ & $1.2 \times 10^{1}$ \\
LS & $4.5 \times 10^{8}$ & $1.8 \times 10^{6}$ & $1.5 \times 10^{2}$ & $1.8 \times 10^{1}$ \\
\hline
\end{tabular}

$\mathrm{LM} / \mathrm{C}=$ Laboratory co-fermented millet/cowpea $\mathrm{LM}=$ fermented millet $\mathrm{LS} / \mathrm{C}=$ Laboratory co-fermented sorghum/cowpea $\mathrm{LS}=$ fermented sorghum/cowpea mixture.

Each value is mean of triplicate values. 
Table 4. The chemical Proximate Composition (g/100g) of Co-fermented millet/cowpea, sorghum/cowpea and their unfermented analogues

\begin{tabular}{|l|l|l|l|l|l|l|}
\hline Sample & Ash & Dry matter & Crude protein & Crude fibre & Lipid content & *carbohydrate \\
\hline LM/C & 1.88 & 87.07 & 11.20 & 2.31 & 2.82 & 68.86 \\
UM/C & 3.35 & 88.80 & 14.0 & 5.34 & 3.20 & 62.91 \\
LS/C & $0 . .85$ & 89.84 & 10.6 & 4.35 & 2.70 & 71.34 \\
US/C & 2.42 & 89.10 & 13.8 & 4.94 & 4.26 & 63.68 \\
\hline
\end{tabular}

Key:

LM/C= Laboratory co-fermented millet/cowpea $\quad U M / C=$ Unfermented millet/cowpea mixture

LS/C= Laboratory co-fermented sorghum/cowpea $\quad U S / C=$ Unfermented sorghum/cowpea mixture.

Each value is mean of triplicate values. ${ }^{*}=$ Calculated by difference

Table 5: The mineral composition of co-fermented sorghum/cowpea, co-fermented millet/cowpea and unfermented samples

\begin{tabular}{|c|c|c|c|c|c|c|c|c|c|}
\hline $\begin{array}{l}\text { Samp } \\
\text { le }\end{array}$ & $\mathrm{P}$ & $\mathrm{Na}$ & $\mathrm{K}$ & $\mathrm{Ca}$ & $\mathrm{Mg}$ & $\mathrm{Fe}$ & $\mathrm{Cu}$ & $\mathrm{Zn}$ & $\mathrm{Mn}$ \\
\hline $\begin{array}{l}\text { LM/C } \\
\text { UM/C } \\
\text { LS/C } \\
\text { US/C }\end{array}$ & $\begin{array}{c}{ }^{\mathrm{bcd}} 128 \pm 0.00 \\
\mathrm{bcd}_{127 \pm 0.00} \\
\mathrm{e}_{178 \pm 0.00} \\
\mathrm{~h}_{1812 \pm 0.00}\end{array}$ & $\begin{array}{l}{ }^{b c} 5.6 \pm 0.26 \\
{ }^{a b} 2.0 \pm 0.00 \\
{ }^{a b c} 4.0 \pm 0.40 \\
{ }^{a b} 2.0 \pm 0.20\end{array}$ & $\begin{array}{l}{ }^{\mathrm{c}} 77.8 \pm 0.70 \\
{ }^{\mathrm{g}} 640.1 \pm 0.10 \\
{ }^{\mathrm{h}} 75.15 \pm 0.00 \\
{ }^{\mathrm{d}} 135.2 \pm 0.10\end{array}$ & $\begin{array}{l}{ }^{\mathrm{cd}} 31.6 \pm 0.45 \\
{ }^{\mathrm{de}} 40.5 \pm 0.55 \\
{ }^{\mathrm{be}} 20.6 \pm 0.00 \\
{ }^{\mathrm{e}} 49.1 .6 \pm 0.10\end{array}$ & $\begin{array}{l}{ }^{\mathrm{a}} 16.2 \pm 0.70 \\
{ }^{\mathrm{e}} 133.8 \pm 0.15 \\
{ }^{\mathrm{c}} 56.6 \pm 0.00 \\
{ }^{\mathrm{h}} 217.6 \pm 0.00\end{array}$ & $\begin{array}{l}{ }^{\mathrm{e}} 34.7 \pm 0.10 \\
{ }^{\mathrm{abcd}} 7.9 \pm 0.07 \\
{ }^{\mathrm{cd}} 14.2 \pm 0.02 \\
{ }^{\mathrm{abc}} 6.1 \pm 0.00\end{array}$ & $\begin{array}{l}{ }^{\mathrm{ab}} 0.47 \pm 0.02 \\
{ }^{\mathrm{ab}} 0.42 \pm \\
{ }^{\mathrm{ab}} 0.46 \pm 0.00 \\
{ }^{\mathrm{bc}} 0.61 \pm 0.00\end{array}$ & $\begin{array}{l}{ }^{\mathrm{a}} 1.41 \pm \\
\mathrm{a}_{3.4 \pm 0.005} \\
\mathrm{a}_{1} 1.4 \pm 0.03 \\
\mathrm{a}_{3.6 \pm 0.00}\end{array}$ & $\begin{array}{l}0.81 \\
0.84 \\
0.93 \\
2.06\end{array}$ \\
\hline
\end{tabular}

LM/C= Laboratory co-fermented millet/cowpea $\quad \mathrm{UM} / \mathrm{C}=$ Unfermented millet/cowpea mixture.

$\mathrm{LS} / \mathrm{C}=$ Laboratory co-fermented sorghum/cowpea US/C= Unfermented sorghum/cowpea mixture.

Each value is mean of triplicate values. Values with the same superscript in each column are not significantly different $(p>0.05)$

Table 4: Fermentation reduced the dry matter of cofermented content when compared with unfermented samples as seen in table 4; however co-fermented sorghum/cowpea had higher dry matter content (89.84\%) than co-fermented millet/cowpea of $87.07 \%$. The crude fibre, lipid content, and crude protein were reduced by fermentation in both samples compared to unfermented samples.

The carbohydrate content of co-fermented samples was higher than their unfermented analogues. This finding agrees with that of Sefa-Dedeh (2001) and Mbata et.al., (2009) reported fermentation decreased carbohydrate content of cereal/legume blend when compared with unfermented samples.

Several researchers had reported loss of minerals during the production of ogi the losses were attributed to loss during sieving and dewatering. Protein energy malnutrition is increasingly being regarded not as deficiency of protein and energy only, but also of minerals like manganese, copper and which zinc are components of key enzymes. The mineral values of samples are shown in Table 5 . The values of sodium and iron were significantly $(p<0) 5$.$) were higher in co-fermented samples than$ their unfermented analogues. The value of phosphorus in co-fermented millet/cowpea and its unfermented counterparts were comparable this means fermentation might not affect the phosphorus and by implication the energy activity of microflora of millet. However the phosphorus value was significantly higher in unfermented sorghum/cowpea than the unfermented counterpart and higher than both co-fermented and unfermented millet/cowpea. The values of calcium and magnesium were lower in co-fermented samples than unfermented ones.

The values of zinc were comparable in cofermented samples but lower than unfermented ones. Copper values were comparable in all cofermented and unfermented samples. Also all samples had comparable values of manganese except unfermented sorghum/cowpea which had significantly $(p<0.05)$ higher value. Overall cofermented millet/cowpea had higher values of calcium and iron; while co-fermented sorghum/cowpea had higher value of magnesium.

The standard Mineral Safety index for minerals for infants are $\mathrm{Na}$ (4.8), mg (15) P (10) Ca (10) Fe (6.7) and Zn (33).(Whitney, et al., 1990). For Ca, the MSI values in this study, (Table 6), both fermented samples were comparable to the standard values, while the value of $\mathrm{mg}$ was slightly lower in co- 
fermented millet/cowpea, the value was higher in sorghum/cowpea, with the negative value of -25.8 between the standard and calculated index. This indicates consumption of co-fermented sorghum/cowpea alone might lead to overload of magnesium. The level of iron was abnormally high in co-fermented millet/cowpea this can inhibit zinc absorption and also lead to iron poisoning in infants. The values of zinc, copper, phosphorus in both samples were lower than standard values. Copper deficiency can cause scarring of the heart muscle and low level of calcium in the bones. Sodium value in both samples was comparable to standard values.

Table 6: The Mineral Safety Index of co-fermented sorghum/cowpea, co-fermented millet/cowpea .

\begin{tabular}{|l|l|l|l|l|l|l|l|l|l|l|l|l|l|l|l|l|l|l|}
\hline & \multicolumn{3}{|c|}{ Ca } & \multicolumn{3}{c|}{ Mg } & \multicolumn{3}{c|}{ Fe } & \multicolumn{3}{c|}{ P } & \multicolumn{3}{c|}{ Cu } \\
\hline sample & TV & CV & D & TV & CV & D & TV & CV & D & TV & CV & D & TV & CV & D & TV & CV & D \\
\hline LM/C & 10 & 0.8 & 9.2 & 15 & 3.0 & 11.9 & 6.7 & 23.2 & -16.5 & 10 & 4.7 & 5.3 & 33 & 23.9 & 9.1 & 4.8 & 0.07 & 4.7 \\
\hline LS/C & 10 & 1.2 & 8.8 & 15 & 40.8 & -25.8 & 6.7 & 4.1 & 2.6 & 10 & 6.7 & 3.4 & 33 & 23.4 & 9.5 & 4.8 & 0.02 & 4.8 \\
\hline
\end{tabular}

Key:

LM/C= Laboratory co-fermented millet/cowpea

LS/C= Laboratory co-fermented sorghum/cowpea

$\mathrm{UM} / \mathrm{C}=$ Unfermented millet/cowpea mixture.

US/C= Unfermented sorghum/cowpea mixture.

Figs 1-2 show the effect of co-fermentation on the viscosity of cereals/cowpea-cooked gruel. The use of Haake Rotovisco is to measure the viscosity of gruels at a temperature of $45^{\circ} \mathrm{C}$ in order to obtain concentration - viscosity relationship of the gruel. At $4 \%$ flour concentration, both co-fermented gruel had comparable values of viscosity value of 0.0089 Pascal per seconds (p.a.s),(1p.a s. $=1000$ centipoise). At $6 \%$ sorghum/cowpea had a viscosity value of 0.2000 p.a.s millet/cowpea 1.291 p.a.s. $^{-1}$. The values of millet/cowpea were significantly higher than that of sorghum/cowpea .At 8\%, sorghum/cowpea gruel had comparable values of 6.591, millet/cowpea, 6.368. At $9 \%$ of flour concentration the sorghum/cowpea and millet/cowpea gruels had comparable viscosity values of 6.6.80p.a.s and 6.680p.a.s respectively. At $10 \%$, sorghum/cowpea was too viscous to be read while millet/cowpea was 1.06 p.a.s ${ }^{-1}$. However the flour concentration of $10 \%$ might be too dilute for adequate nutrient density thus a careful balance has to be established while formulating complementary food for infants in terms of flour concentration, viscosity, consistency and their attendant's effects on nutrient and energy density. The recommended viscosity of complementary food is in the range of 1-3 p.a.s- ${ }^{1}$ At $4 \%$ and $6 \%$ sorghum/cowpea and millet/cowpea gruels had comparable dry matter and consistency values of $3.70 \mathrm{~g} / 100 \mathrm{~g}, 21 \mathrm{~mm} / \mathrm{sec}$, and $3.80 \mathrm{~g} / 100 \mathrm{~g}$ and $21.5 \mathrm{~mm} / \mathrm{sec}$. respectively. Dry matter of sorghum/cowpea was $5.30 \mathrm{~g} / 100 \mathrm{~g}$ the consistency $10 \mathrm{~mm} / \mathrm{sec}$, for millet/cowpea gruel, dry matter value was $5.42 \mathrm{~g} / 100 \mathrm{~g}$ and consistency $9.60 \mathrm{~mm} / \mathrm{sec}$.. At
$8 \%$, sorghum/cowpea gruel had a dry matter content of $7.41 \mathrm{~g} / 100 \mathrm{~g}$ with a consistency value of $4.5 \mathrm{~mm} / \mathrm{sec}$, millet/cowpea gruel had a dry matter value of $7.58 \mathrm{~g} / 100 \mathrm{~g}$ and a consistency value of $3.75 \mathrm{~mm} / \mathrm{sec}$. the dry matter and consistency value of millet/cowpea was significantly $(p<0.05)$ higher than sorghum/cowpea gruels. At $9 \%$, sorghum/cowpea gruel had a dry matter value of $8.03 \mathrm{~g} / 100 \mathrm{~g}$ and a consistency value of $3.4 \mathrm{~mm} / \mathrm{sec}$, this was a comparable value to millet/cowpea dry matter value of $8.03 \mathrm{~g} / 100 \mathrm{~g}$ and a consistency of $3.70 \mathrm{~mm} / \mathrm{sec}$. At $10 \%$, sorghum/cowpea gruel had a dry matter value of $9.70 \mathrm{~g} / 100 \mathrm{~g}$ and consistency of with a consistency of $0.82 \mathrm{~mm} / \mathrm{sec}$ while maize/cowpea gruel had a dry matter value of $9.24 \mathrm{~g} / 100 \mathrm{~g}$ and a consistency value of $1.0 \mathrm{~mm} / \mathrm{sec}$. Generally, it was observed the higher consistency values the less the dry matter values.

Thus, there is a strong negative relationship between flour dry matter and Bostwick flow of gruel ( $R$ value of -0.83 to -0.97 ). These results show the dependence of Bostwick flow on flour concentration furthermore, flour concentration can significantly influence Bostwick flow and dry matter. 


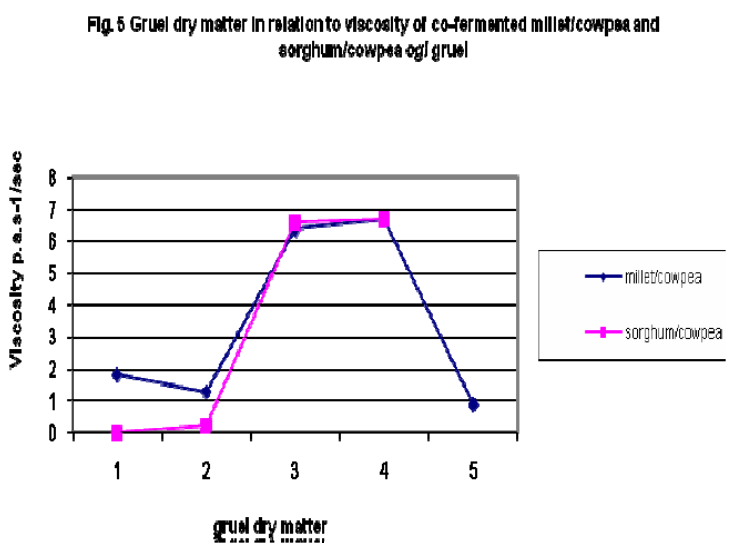

Fig.6 Effect of dry matter on consistency of co-fermented millet/cowpea and sorghu/cowpea ogi gruel

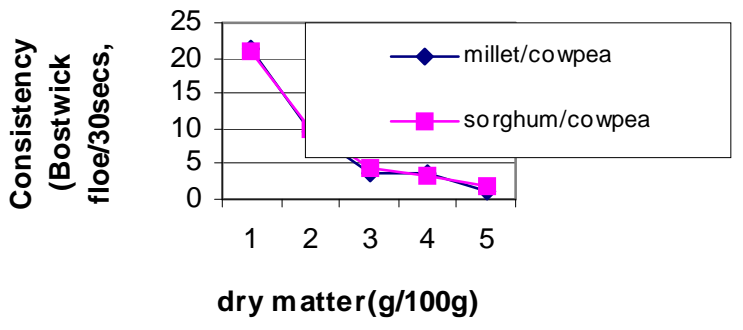

\section{DISCUSSION}

There was concurrence decrease in $\mathrm{pH}$ with increase in fermentation time the decrease was more pronounced at $72 \mathrm{hrs}$ to $\mathrm{pH}$ of 4.0 which is inhibitory to most bacterial growth.

However, the decrease in the $\mathrm{pH}$ of co-fermented samples might be due to availability of more nutrients probably from cowpea that can enhance microbial metabolic activities and probably increase proliferation of other microbes like yeasts/ moulds. However the population of moulds and yeasts in this work was more reduced than the reported population by Sanni, et al., (2002). Yeasts and moulds in this work may also be contaminants in cereals Abegaz et al., (2002); and may not appear to play any significant role in the fermentation process however microbial interactions of mixedbacterial, fungal-yeasts and yeasts-bacterial combinations in indigenous fermentation may play an important role in the nutritional, safety and sensory characteristics of the end product. The development of lactic acid bacteria is also stimulated by the presence of yeasts which provide soluble nitrogen compounds and factors like Bvitamin (Hama, et al., 2009).

The predominance of $L$. plantarum, $L$. brevis in this study may be due to secretion of lactic acids which inhibits greater growth of other bacteria and yeasts in the fermenting medium. This is in agreement with Chavan (1998) who reported lactic acid bacteria as one of major microorganisms involved in fermentation of sorghum green-gram blend. The increase of yeasts and moulds in millet/cowpea than sorghum/cowpea might be due to utilization of more available oxygen and production of carbon dioxide which might inhibit the growth of potential spoilage microorganism like Enterobacteriaceae. (Abegaz et al., 2002). The small number units of Enterobacteriaceae and other gram- negative bacteria showed that their growth might have also been inhibited due to the presence of lactobacilli which produced lactic acid. (Omemu ,et al., 2007).

However in this study, the total plate counts were higher in millet/cowpea compared to sorghum/cowpea counts this may be due to solubilization of protein since structurally millet is richer in protein than sorghum, the solubilization might have buffered the acid produced thus giving less inhibitory effect on Enterobacteriaceae than in sorghum/cowpea mixture. The mixture of total plate counts showed both homo-fermentative and heterofermentative bacteria this is in agreement with the finding of Mbata et al., (2009).

In proximate composition. The decrease in dry matter in co-fermented samples compared to unfermented samples might be due to lactic acid accumulation with concomitant increase in acidity and a decrease of dry matter yields. Our finding of dry matter decrease in co-fermented mixture compared to unfermented samples is in agreement with the finding of Sefa-Dedeh (2001) and Mbata et al., (2009).Also milling and dewatering during product preparation might have contributed to loss of part of the solid materials. However, the general low moisture content of co- fermented samples indicates that the product will have a good keeping quality since spoilage microbes thrive better in the presence of adequate moisture. 
The fibre values were significantly reduced in cofermented samples compared with their unfermented counterparts. The low values of fibre are desirable because possible undesirable aspects of high fibre levels in weaning period include ; increased bulk and lower calorie density, irritation of the gut mucosa, reduced digestibility, reduced vitamin and mineral availability and local effects on intestinal mucosa in infants. The calorie density of a cereal will be lowered by fibre (Jansen 1980). Protein Advisory Group (PAG) of the United Nations suggests an upper limit of $5 \%$ crude fiber in complementary food and recommended $2 \%$ in cereal/legume blends. The older concept of crude fiber consists basically of measuring the residue remaining after acid and basic hydrolysis which covers $50-80 \%$ of the cellulose, $10-50 \%$ of the lignin and 20\% of hemicelluloses (Robertson 1980, while Dietary fiber is defined as the edible portion of plant material that human gastro intestinal enzymes cannot break down. The components of fiber have been classified according to their solubility in water. pectins ,uronic acids, gums and some hemicelluloses are soluble while cellulose, lignin and other hemicelluloses are insoluble. It is suspected that Bacteroides and Eubacterium become the preponderant flora of the colon only during the second semester of life and other anaerobic fermentative genuses may be present in the gut as early as first few days after birth depending on the mode of delivery (Agostoni,et al., 1997).

The carbohydrate content of co-fermented samples decreased compared to unfermented samples this agrees with the observation of Sefa-Dedeh (2001) and Mbata et al., (2009); that addition of legumes decreased carbohydrate of cereal-based traditional foods. The protein content of both co-fermented samples were comparable The protein value was higher in millet/cowpea than sorghum/cowpea; even though in vivo and in vitro studies indicate that protein of sorghum are reported to be significantly less digestible than the protein of other similarly cooked cereals.(Duodu et al., 2002).

The germ and aleurone layers millet and sorghum contribute lipid. The presence of lipid in cereal starches is a distinguishing feature of the starches in this study co-fermentation appeared to decrease the lipid content this agreed with the finding of Oyarekua and Adeyeye (2008).
Reduction in lipid content might be due to oxidation of fatty acids by microorganisms to obtain energy for metabolic activities. This reduction may also lead to reduction in fat content which can enhance storage ability and keeping quality of fermented foods. PAG (1971) guidelines for complementary foods are protein $20 \%$ (dry weight), fat levels $10 \%$, moisture $5-10 \%$ and total ash not more than $5 \%$.

Generally, the proximate composition of cereal/legume mixture did not change much during fermentation in this work and this is in agreement with Omueti, et al., ( 2009); but there might be $a$ is an increase in the soluble fraction of a food during fermentation.

The storage protein of cowpea is vicilin which show high solubility range at a wide $\mathrm{pH}$ range. Doudu, et al., (2003); Exogeneous, endogeneous factors like disulphide and non-disulphide cross-linking changes in protein secondary structure, may be a factor that influence protein digestibility, this bond must have been broken by hydrolytic action of alpha-amylaseduring fermentation process, on starch granules thus increasing the solubility and by implication reducing the crude protein content. It has been reported that fermentation reduced crude protein though not protein quality and bioavailability (Oyarekua and Adeyeye2008).the protein values did not meet the $14 \mathrm{~g} / 100 \mathrm{~g}$ digestible protein recommended for 6-12months if any of these product is consumed alone by an infant.

Viscosity: This study used 5 mins for boiling time and $45^{\circ \mathrm{CC}}$ for gruel temperature for viscosity and consistency measurement and it was concluded that fermentation did not decrease the viscosity of cereal/cowpea fermented mixture in agreement. Griffith et al., (1998) in blending cereal/legume reported that fermentation did not reduce the viscosity of $60 \%$ cereal and $40 \%$ legume. Viscosity reduction is due to amylolytic activity (Lorri and Svanberg 1993).

The lower value of fat in co-fermented samples compared to their unfermented analogues might be responsible for lower viscosity values of cofermented mixtures because fat do not absorb water in gruel preparations. Also, in some cases the microorganisms are capable of producing pectinases and cellulases softening the texture of the products and liberating sugars that would otherwise be unavailable to the human digestive 
system. Thus fermented foods are expected to be more digestible than their unfermented counterparts. Also the main protein, vicillin with isoelectric point been at lower $\mathrm{pH}$ than observed in this work,will have higher solubilization that might reduce viscosity this agrees with Pereira et al., (2009).

Minerals: Zinc it is a limiting factor in the growth of severely malnourished infants especially in developing countries; because the diets are low in animal products and high in phytates. Deficiency of zinc may negatively affect the behavioral development and growth of infants. Zinc loss might also occur as a result of diarrhea (WHO/NUT/98).

Table 5 in this study, Zinc content was significantly lower $(p>0.05)$ in co-fermented cereals/cowpea than their unfermented analogues This contradicts the finding of Chavan and Kadam (1989b) that reported that fermentation of corn plus soy blend decreased the solubility of phosphorus and iron. But zinc values were comparable $(1.4 / 100 \mathrm{mg})$ in both co-fermented mixtures, thus the consumption of any the co-fermented product may not lead to significant increase in the growth of 11-23 months infants Oyarekua (2009); because these values are lower than British $(4.7 \mathrm{mg} / 100 \mathrm{~g})$ or Krebbs $(2.08 \mathrm{mg} / 100 \mathrm{~g}) \quad$ standards required from complementary foods for $11-23$ months based on daily consumption of $750 \mathrm{ml} / \mathrm{d}$ (WHO/NUT/98) and lower than $10 \mathrm{mg} / 100 \mathrm{~g}$ required from supplementary foods for older infants and young children(CODEX 1991).

Sodium: Together with chloride sodium functions in maintenance of extracellular fluids (ECF) and blood pressure. The co-fermentation significantly increased sodium content of co-fermented cereals/legume than the unfermented samples. A similar pattern was observed for iron. Only $10 \%$ of all dietary iron is absorbed through the small intestine into the blood. The rest passes out of the body with feaces. Iron intake is inadequate during 6 months to 4 years of age because of low iron content of milk and rapid growth rate in infants and children. Infants need iron to meet the need for red blood cells synthesis and growth. Deficiency of iron can be severe resulting in anemia. Iron deficiency anemia is also a risk factor for abnormal cognitive, social development as well and neuro-psychomotor development. The adverse effect of anemia like depressed growth and persist even if the anemia is corrected during infancy. in this study iron content is greater in un-fermented millet/cowpea than in sorghum/cowpea and agrees with $4.2 \mathrm{~g} / 100 \mathrm{~g}$ in whole kernel sorghum and $8.0 \mathrm{~g} / 100 \mathrm{~g}$ in whole kernel millet Nwokolo (1987) this the same trend in iron distribution and that cowpeas iron distribution was not significant in the unfermented blend. Iron values in this work were higher than RDA of $17.8 \mathrm{mg} / 100$ (low breast milk intake) and 9.13 $\mathrm{mg} / 100 \mathrm{~g}$ (medium breast milk intake) and lower than $5.8 \mathrm{mg} / 100 \mathrm{~g}$ (high breast milk intake) expected from complementary foods. However the values in both co-fermented samples were significantly higher than the reference daily requirement of $12 \mathrm{mg} / 100 \mathrm{~g}$ adopted by CODEX (1991) on formulated supplementary foods for older infants and young children.

decrease in the values of magnesium, calcium showed that fermentation did not release bound calcium and magnesium.RDA for calcium is 295mg/day-1 for ages 9-11mnths (based on daily consumption of 250 mlday- 1 and in excess of the required calcium (average of 2950 for 11-23 based on daily consumption of $750 \mathrm{mLday}-1)$.

However the co-fermented samples had significantly $(p>0.05)$ higher level of iron than unfermented samples microorganisms in the fermenting medium must have solublized iron during their metabolic activities. In this study for infants 6-23 months the iron value in co-fermented millet/cowpea was higher than estimated iron need from complementary food by level of usual breast milk intake in low bioavailability of iron (mg/day) (WHO/NUT /98.1 1998); and excess the value in co-fermented sorghum/cowpea was higher than estimated iron need for medium bioavailability of iron .Excess iron can lead to iron poisoning in children (Oyarekua and Adeyeye, 2008).

Calcium: If $\mathrm{Ca} / \mathrm{P}$ ratio is low (low calcium, high phosphorus intake) more than normal amount of calcium may be lost in the urine and thus decrease calcium level in bones. Calcium is needed for bone and teeth formation and its deficiency can lead to rickets in infant and children. Calcium values in this study were higher in unfermented samples than cofermented samples. Also, the value was higher in unfermented millet/cowpea than in unfermented sorghum/cowpea, which corresponds to trend of whole kernel millet of $46 \mathrm{mg} / 100 \mathrm{~g}$ and $15 \mathrm{mg} / 100 \mathrm{~g}$ in sorghum this indicates that the presence of cowpea 
and in the blend did not affect calcium distribution. The calcium value in both co-fermented samples were significantly ( $00>0.05)$ lower than $255 \mathrm{mg} / \mathrm{d}$ required from complementary foods for 6 23 months infants. than $8000 \mathrm{mg} / 100 \mathrm{~g}$ required from supplementary foods for older infants and young children(CODEX 1991).

For the contents of magnesium, potassium and calcium in this study, unfermented samples had higher values than fermented samples. Phosphorus: In this study, the values of phosphorus were significantly $(\mathrm{p} 0>0.5)$ higher in both co-fermented samples than required phosphorus need from complementary food for $6=23$ months. This might be due to the fact the microorganisms in the fermenting medium might not have utilized phosphorus for their metabolic activities. The content is greater in sorghum/cowpea than in millet/cowpea and both values were lower than reported levels of $352 \mathrm{mg} / 100 \mathrm{~g}$ in whole sorghum and $379 \mathrm{mg} / 100 \mathrm{~g}$ in whole millet kernels; this might be due to the fact that fermentation process and the presence of cowpea had no effect on phosphorus distribution. After calcium, phosphorus is the most common mineral found in the body and it teams with calcium in many of its roles. Sixty to seventy per cent is absorbed in the small intestine. Deficiency in phosphorus can lead to lack of appetite, general tiredness and muscle pain.

Magnesium is the most abundant ion in plant cells. It is needed for more than 300 different enzymes systems in the body. It is important in formation of adenosine trio phosphate, storage of carbohydrates, fats and protein, in nerve and muscle activity. Human body has a remarkable capacity to conserve magnesium. In this study, magnesium content was higher in sorghum/cowpea than millet/cowpea this agreed with the report that magnesium level of $171 \mathrm{~g} / 100 \mathrm{~g}$ in sorghum whole kernel was higher than $137 \mathrm{~g} / 100 \mathrm{~g}$ of millet whole kernel. However, according to Nwokolo (1987), the bioavailability of magnesium was reported to be higher in millet than in sorghum. Magnesium requirement is $525 \mathrm{mg}$ day-1 for $6-12$ months and $350 \mathrm{mg} /$ day-1 for $12-23$ months /day

Potassium values were comparable in both samples; while millet/cowpea had higher sodium value of $77.8 \mathrm{mg} / 100 \mathrm{~g}$ than that of sorghum/cowpea of $75.1 \mathrm{mg} / 100 \mathrm{~g}$. Both values were significantly lower than their unfermented analogues, Sodium and Potassium: Sodium is the major cation of fluids in the body cells. Sodium and potassium ratio of 0.60 is recommended; this means man should consume $40 \%$ more potassium than sodium to balance blood electrolyte. The ratio in this study was 0.07 for millet/cowpea and 0.23 for sorghum/cowpea. The values of sodium and potassium in both co-fermented samples were significantly $(p>0.05)$ lower than required values from complementary foods of 6-23months old infants.

Copper is necessary for blood formation as part of several important enzymes that are needed for the manufacture of haemoglobin and the red blood cells in bone marrow. Copper helps in nerves and cardiovascular systems, immune and blood clotting systems. According to Castillo-Duran and Uauy (1988) copper supplement improved food intake and weight gain of children recovering from severe malnutrition. The copper content in millet/cowpea was comparable to that of sorghum/cowpea this disagrees with the trend of higher value of $1.06 \mathrm{mg} / 100 \mathrm{gin}$ whole millet compared with $0.44 \mathrm{mg} / 100 \mathrm{~g}$ in whole sorghum. The Cowpea's presence must have affected the values of copper maybe its microflora utilized copper for their metabolic activities during the fermentation process. The copper content in both co-fermented samples were higher than the value required from complementary foods. Copper requirement RDA from complementary food is 1-2ug for 11-23 month based on $750 \mathrm{ml}$ day-1 for 11-23mnths. Cu deficiency is of little concern because it is widely distributed in plants.

Manganese: is a component of enzymes that are involved in antioxidant pathways and it helps in proper functioning of the brain and spinal cord. Deficiency can lead to defective growth abnormalities, central nervous systems and disturbances in the way the body handles fats (Nieman, et al., 1992). In this study, both cofermented samples had comparable value and the values were significantly lower $(p>0.050)$ than required value from complementary foods. (WHO/NUT/98.1, 1998).

Table. 2 Ash content of millet/cowpea was 0.90\% and was significantly higher $(p<0.05)$ than sorghum/cowpea of $0.36 \%$ however whole kernel sorghum has $1.67 \%$ and whole kernel millet is 
$1.7 \%$. Co-fermentation process especially sieving and dewatering stages might have reduced the ash content of both samples. Zinc, iron, magnesium and manganese contents were higher in millet/cowpea than sorghum/cowpea. This finding agreed with Nwokolo (1987) who reported higher bioavailability of these minerals in millet than in sorghum.

Mineral Safety Index.: Table 6. Mineral Safety index (MSI) is a numerical statement of the safety doses of minerals in relation to the United States RDA(Whitney, Hamilton and Rolfes (1990)

Some minerals taken in large amount can result in abnormally high levels in the blood. The recommended infant intake, tabulated value (TV), calculated value (CV) and mineral safety index of some major and minor minerals are shown in Table 6 . The values of calcium were comparable to recommended $\mathrm{MSI}$ in both samples; while the values of copper, zinc and phosphorus were significantly $(p>0.05)$ lower than MSI values. Deficiency of copper can cause scarring of the heart muscles in animals; that of calcium can lead to low levels of calcium in bone; while deficiency of zinc can decrease the functioning of the immune system. However, iron was significantly higher in millet/cowpea than recommended MSI values. Excess iron could lead to iron poisoning in the blood.

The presence of cowpea in co-fermentation process appeared to have been responsible for high number of propagnules of yeasts and moulds and Enterobacteriaceae in millet/cowpea which would have been otherwise inhibited by the presence of lactobacilli which produced lactic acid; or might be due to solubilization of protein since structurally millet is reported richer in protein than sorghum, this might have buffered the acid produced thus giving less inhibitory effect. Due to the strong negative relationship between flour, dry matter Bostwick flow (consistency), a careful balance has to be established while formulating complementary food in terms of flour concentration, Bostwick flow and its attendant effect on nutrients and energy density. Millet/cowpea and sorghum/cowpea might not be acceptable in terms of iron and magnesium respectively. Co fermentation reduced phosphorus in all the samples while the process did not affect the values of copper, sodium and zinc in all the samples. Fermentation increased iron and phosphorus in both samples. $\mathrm{Mg}, \mathrm{K}, \mathrm{Ca}$ and ash contents were significantly reduced by fermentation. Millet/cowpea had comparable $\mathrm{Na}: \mathrm{K}$ ratio to RDA value. $\mathrm{Zn}, \mathrm{Fe}, \mathrm{Mg}$ and $\mathrm{Mn}$ values were higher in millet/cowpea than sorghum/cowpea.

\section{ACKNOWLEDGEMENTS:}

The author wish to acknowledge the Department of Botany and Microbiology; The University of Ibadan for the use of their facilities.

\section{REFERENCES}

Abegaz, K. Fekadu, B. Langsrud, T and Narvhus, J.A (2002). Indigeneous Processing Methods and Raw Materials of Borde, an Ethiopian traditional Fermented Beverage. J.Food Technology. 7(2): 5964ad-hoc Project, Mahatma Phole Agriculture University, Rahuri, India .

Agostoni, C., Riva, E and Marcello Giovanni, M (1997). SUPPLEMENT:pp 1002-1004.

Akinrele, I. A and Edwards, C.C.A (1971). An Assessment of the Nutritional Value of Maize-Soya Mixture "Soy-'ogi"' as a Weaning Food in Nigeria. British Journal of_Nutrtini. 26:177-185.

AOAC (2005). Official Methods of Analysis. $17^{\text {th }}$ Edn. Association official Analytical Chemists. Washington D.C.pp.18.

Afoakwa, E.O., Sefa-Dedeh, S. Simpson Budu, S . Sakyi-Dawson. A.E., and Asomaning J (2007). Some Quality Characteristics of Maize Based Cowpea-fortified Nixtamalized Foods. African Journal of Food Agric Nutrition and Development 17: $1 \quad$ Assessed $\quad$ Feb $4^{\text {th }}$ 2010:http.www.guidelines.gov/summary.aspx?doc_i $\mathrm{d}=8$

Bressani, R (1985). Nutritive value of cowpea. In: Cowpea Research,Production and Utilization . Edited by S.R. Singh and K. O. Rachie. John Wiley \& Sons Ltd. New York.

Brown, K.H., Dickins, M.E Bentley, G.A Oni, V.T Obasaju, S.A., Esrey, S. Mebrahtu, I. Alade, I and Stallings R.V ( 1988). Consumption of Weaning Foods From Fermented Cereals: Kwara State. In: Alnwick, D., Moses S. and Schmidt O. G. (Eds). Improving Young Child Feeding in Eastern and Southern Africa pp. 181-197. Centre de Recherché pour le Development International. Nairobi, Kenya

Casitillo-DuRan, C. and Uvuay, R (1988). Copper Deficiency Impairs Growth of Infants Recovering from Malnutrition. American Journal of Clinical Nutrition. 47: 710-714.

Chavan, J. K (1998). Malting and fermentation of sorghum- legume blends for improvement in nutritional and bhakhari making quality. Final Report 
of ICAR ad-hoc Project, Mahatma phole Agriculture University, Rahuri, India .

Chauvan, J.K and Kadam, S (1989b). Nutritional Improvement of cereals by fermentation.CRC Critical Review in Food Science and Nutrition 28 (5): 349-400.

CODEX (1991). The Guidelines on Formulated Supplementary Foods for Older Infants and Young Children adopted by CODEX Alimentarius Commission at its $19^{\text {th }}$ session 1991.

Dada, L.O and Muller, R.H.G (1983).The fate of aflatoxin $\mathrm{B} 1$ in the production of 'ogi', a Nigerian sorghum porridge. Journal of Cereal Science. 1: 63.

Danjanta, K.S., Wongkham, S., Thirach, P., Baophoeng, A., Apichartsrangkoom, P., Santithum and Chukeatirote, E (2009). Comparattive Study of Proteolytic Activity of Protease-Producing bacteria isolated from thua nao. Majeo Int. J.Sci. Technol. 3(02): 269-270.

Duodu, K.G., Taylor, J.N.R., Belton, P.S and Hamaker, B.R (2003). Mini-Review-Factors Affecting Sorghum Protein Digestibility. Journal of Cereal Science.197. Nairobi Kenya, Centre de Recherché pour le Development International.

Duodu, K.G., Nunes, A., Delgallo, I. Parker, M.L., Mills, M.L.P.S., Belton, P.S and Taylor J.N.R (2002). Effect of Grain Structure and Cooking in vitro Protein Digestibility. Journal of Cereal Science.35:161-1784.

Fields, M.L (1980).Improvement in Nutritive quality of Cereals and legumes by Fermentation and Germination. Bioletin Tenico LABAL 1 (4): 14-16.

Griffith, L.D., Castell-Perez, M.E and Griffith, M.E (1998). Effects of Blend and Processing Method on the Nutritional Quality of Weaning Food made from Select Cereals and Legumes. Cereal Chemistry 75: (1): $105-112$.

FAO/WHO (1998). Carbohydrates in Human Nutrition. In: International Report of a Joint Expert Consultation. Rome: FAO/WHO.

Hama, F., Savadogo, A., Outara, C.A.T and Traore, S (2009). Biochemical, microbial and processing study of Degue- a fermented food (from pearl millet dough). Pakistan Journal of Nutrition 8 (96):759-764.

Jansen, G.R (1980). A Consideration of allowable Fibre Levels in Weaning Foods. Food and Nut Bull 2 (4): 38-46.

Lonner, C., Welander, T., Molin, N and Dostalek, M. (1986). The Microflora in a Sour Dough Started Spontaneously on Typical Swedish rye Meal. Food Microbiol.3(2):3-12

Lorri, W. and Svanberg, U (1993). Lactic and fermented gruels with improved in vitro protein digestibility.
International Journal of Biological Chemistry 193: 265-275.

Mbata, T.I Ikenebomeh, M.J and Ahonkhai, I ( 2007). Nutritional Status of Maize Fermented meal by Fortification with bambara-Nuts-African J. of Food Agric. Nutrition and Development. 7

Mbata, I.T., Ikenebomeh, M.J and Ahonkai, I (2009). Studies on the microbiological, nutrient composition and antinutrition contents of fermented maize flour fortified with bambara groundnut (Vigna subterranean L). African Journal of Food Science 3(6): 165-171.

Nieman, D.C., Butterworth, D.E and Nieman, C.N (1992). Nutrition. Revised First Edition pp 273-308. Publisher wim.C. Brown Publisher

Nout, M (2009). Rich Nutrition from the Poorest: Cereals Fermentation in Africa and Asia.- Food Microbiology.26: 682-692.

Nwokolo, E. (1987) Composition and Availability of Nutrients in some Tropical Grains and Oilseed. Nutr. Rep. Int. 36 (3):631-640

Ojofeitimi, E.O., Afolabi, O.A and Fapojuwo, O.O (1984).The Use of Black-eyed Cowpea- Maize Gruel Mixture "Ewa- 'ogi"' in the Prevention of Infantile Protein Malnutrition. Nutrition Reports International. 30 (4): 841-852.

Omemu, A.M., Oyewole, O.B and Bankole, M.O (2007). Significance of Yeasts in the Fermentation of 'Ogi' production. Food Microbiology . 24(6): 571-576.

Omueti, O.O., Jaiyeola, B. Otegbayo, Ajomale, K., Afolabi, O (2009).Development and Quality Evaluation of Low Cost High Protein Weaning Foods Types:Browena and Propalm from Soybean (Glycine max) Groundnut(Arachis hypogeal) and Crayfish (Macrobrachim spp.). British Fd.Journal. 3(2):196204.

Osundahunsi, O.F and Aworh, A.C (2002). A Preliminary Study on the use of Tempe-Based Formula-Plant Foods and Human Nutrition . 57 (3-4):365-376.

Oyarekua, M.A (2009) Co-fermentation of cassava/cowpea/carrot to produce infant complementary food of improved nutritive quality. Asian J. of Clinical Nutrition 1(3):120-130

Oyarekua, M.A and Adeyeye, E.I (2008). Comparative Evaluation of the Nutritional Quality, Functional Properties and Amino Acid profile of Co-fermented maize/cowpea and Sorghum/cowpea Ogi as Infant Complementary Food. Asian Journal of Clinical Nutrition 1 (1):31-39.

Oyeyiola, A (1990). Microbiolol'ogi'cal and Biochemical Changes During The Fermentation of Maize (Zea 
mays) Grains For Masa-Production. World Journal of Miccrobiolology and Biotechnology. (6):171-177.

Pereira, H.V.R., Saraiva, K.P., Carvalho, L.M.J., Andrade, L.R. Pedrosa, C and Pierucci, A.P.T.R (2009). Legumes seeds protein isolates in the production of ascorbic acid microparicles. Food Research International 42:115-121.

Robertson, J.B (1980). The Detergent System of Fiber Analysis. In: Topics in Dietary Fiber. Spiller G. A ed; Plenum press, New York pp.1

Sanni, A.I,. Sefa-Dedeh, S., Sakyi-Dawson, E and Asiedu, M (2002). Microbiological Evaluatuion of Ghanian maize-Dough Co-fermented with Cowpea. Int. J. of Fd Sci \&Nutri . 53 (5):367-373.

Sefa-Dedeh, S. Sakyi-Dawson, E (2001). Effect of Drying Method, Packageing Material and Storage on the Quality of Cowpea-based Weaning Foods. Paper Presented at the Annual Meeting of the Institute of Technology, New Orleans, USA. Pp. 2528.
Teniola, O.D and Odunfa, S.A ( 2002). Microbial Assessment and Quality Evaluation of Ogi during Spoilage- World J. Microbiol .Biotechnol. 18: 731737.

Wannik, J. F., Vilet-T. Van,. Nout, M.J.R and Van Vilet, $T$ (1994). Effect of Roasting and Fermentation on Viscosity of Cereals -Legume Based Food Formulas. Plant Foods for Human Nurition. 46 (2): 117-126.

Whitney, E.N., Hamilton, E.M.N and Rolfes, R.F (1990). Understanding Nutrition pp. 430-453.publ. West Publishing Company. St. Paul, N. York, Los Angeles and San Francisco.

WorldHealth Organization (WHO/UNU.98)(1998). Complementary Feeding of Infants and Young Children. Report of a Technical Consultation Supported by WHO/UNICEF. University ofCalifornia/Davies and ORSTOM, WHO, NUT/96-9. 